Primljen / Received: 10.9.2015. Ispravljen / Corrected: 2.3.2016.

Prihvaćen / Accepted: 22.7.2016.

Dostupno online / Available online: 10.4.2017.

\title{
Optimizing activated carbon size and ratio in bitumen modification
}

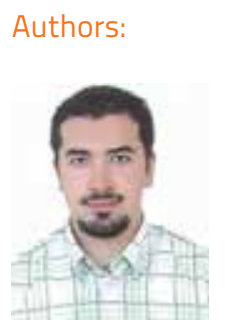

Asst. Prof. Murat Bostancioğlu, PhD. CE Cumhuriyet University Civil Engineering Department Sivas, Turkey bostancioglu@cumhuriyet.edu.tr

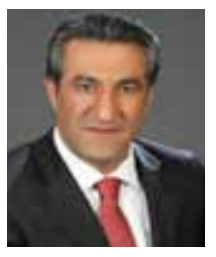

Assoc.Prof. Şeref Oruç, PhD. CE Karadeniz Technical University Civil Engineering Department Trabzon, Turkey oruc@ktu.edu.tr

\begin{abstract}
Murat Bostancioğlu, Şeref Oruç
\section{Optimizing activated carbon size and ratio in bitumen modification}

The aim of the study is to investigate the effects of activated carbon $\left(C_{A}\right)$ on the rheology of bitumen, and to optimize the activated carbon size and ratio in bitumen modification. The use of $C_{A}$ produced from waste hazelnut shells in bitumen modification is evaluated. Different sizes and ratios of $C_{A}$ are used. Test results show that a $C_{A}$ particle size smaller than $0.063 \mathrm{~mm}$ is the most effective, and that the $C_{A}$ modification increases the bitumen consistency and high temperature performance, while reducing the temperature susceptibility and weight change.
\end{abstract}

Key words:

activated carbon, modification of bitumen, dynamic shear rheometer, ageing

Stručni rad

\section{Murat Bostancioğlu, Şeref Oruç}

\section{Optimiziranje veličine i udjela aktivnog ugljena pri modifikaciji bitumena}

Svrha je ovog rada istražiti učinke dodatka aktivnog ugljena $\left(C_{A}\right)$ na reološka svojstva bitumena te optimiziranje veličina i udjela aktivnog ugljena pri modifikaciji bitumena. Za modifikaciju bitumena vrednovana je primjena aktivnog ugljena proizvedenog iz otpadnih ljuski lješnjaka. Upotrijebljene su različite veličine i udjeli aktivnog ugljena. Rezultati ispitivanja pokazuju da je veličina čestica aktivnog ugljena manja od 0,063 mm najučinkovitija, a da modifikacija s aktivnim ugljenom povećava bitumensku konzistentnost i radna svojstva pri visokim temperaturama te umanjuje osjetljivost na temperaturu i promjenu mase.

Ključne riječi:

aktivni ugljen, modifikacija bitumena, dinamički smični reometar, starenje

Fachbericht

Murat Bostancioğlu, Şeref Oruç

\section{Optimierung von Größe und Anteil der Aktivkohle bei Bitumenmodifikationen}

Das Ziel dieser Arbeit besteht darin, die Auswirkungen des Zusatzes von Aktivkohle $\left(\mathrm{C}_{\mathrm{A}}\right)$ auf rheologische Eigenschaften von Bitumen zu untersuchen, sowie Größe und Anteil von Aktivkohle bei Bitumenmodifikationen zu optimieren. Dabei wurde der Zusatz aus Abfällen von Nussschalen gewonnener $C_{A}$ bewertet. Es wurden verschiedene Größen und Anteile von $C_{A}$ untersucht. Die Resultate der Untersuchungen zeigen, dass bei Größen unter 0,063 mm die $C_{A}$ Teilchen am wirksamsten ist. Ebenso erhöht eine Modifikation mit $C_{A}$ die Konsistenz des Bitumens, erleichtert die Bearbeitung bei hohen Temperaturen und mindert die Empfindlichkeit auf Temperaturänderungen sowie die Massenschwankung.

Schlüsselwörter:

Aktivkohle, Bitumenmodifikation, DSR, Alterung 


\section{Introduction}

Bitumen is an organic mixture of various chemical elements and compounds. It is widely used for the construction of roads due to its good adhesion to mineral aggregates and its viscoelastic properties [1-3]. Unfortunately, bitumen assumes the form of liquid at high temperatures and becomes brittle at low temperatures, which can limit its application by causing high temperature rutting and low temperature cracking of pavement $[1,4]$. Continuous increase in traffic volume and load on roadways, combined with adverse climatic effects, result in serious rutting and cracking occurrences. The improvement of bitumen and bituminous mixture properties by means of appropriate additives is an important issue in bitumen industry [5].

The additives used for bitumen modification include polymers, carbonaceous materials, and other materials of various origin [6]. Pavements with modified bitumen exhibit greater resistance to permanent deformation, fatigue damage, thermal cracking, stripping, and temperature susceptibility $[1,4]$.

$C_{A}$, the additive used in this research, is a highly porous and amorphous carbon-based material. Due to its high degree of microporosity, it is used in the absorption of gases and soluble substances from water. $C_{A}$ is produced from carbonaceous source materials such as nut shells, coconut husk, wood, and coal [7-10].

The purpose of the present study is to investigate the effects of $C_{A}$ addition on the rheology of modified bitumen through conventional softening point and penetration tests, thin film oven test (TFOT), and Superpave methods (rotational viscometer $(\mathrm{RV})$ and dynamic shear rheometer (DSR)). The $\mathrm{C}_{\mathrm{A}}$ used in this study has been obtained by pyrolysis of hazelnut shells. The effects of $C_{A}$ size and ratio on the rheology are also evaluated.

\section{Materials and methods}

The 50/70 penetration grade bitumen (original bitumen) obtained from the Kırıkkale terminal of the Turkish Petroleum Refinery was used throughout the study. Physical and rheological properties of the original bitumen are given in Table 1.

\subsection{Production and characterization of $C_{A}$}

$C_{A}$ was produced from hazelnut shells obtained from the Giresun region of Turkey. The hazelnut shells were dried, crushed, and sieved to a particle size fraction of 1.0-2.0 millimetres. Chemical activation was applied in order to obtain a porous surface texture. During the activation procedure, hazelnut shells were saturated with $30 \% \mathrm{H}_{2} \mathrm{SO}_{4}$. The resulting chemical-loaded sample was placed in a furnace and heated $\left(12.5^{\circ} \mathrm{C} \mathrm{min}^{-1}\right)$ to the final carbonization temperature of $450^{\circ} \mathrm{C}$ for 2 hours $[7,8,10$, 11]. After cooling to room temperature, the resulting products were taken out and leached with distilled water until the $\mathrm{pH}$ 7.0 was reached $[7,12,13]$. The porous surface texture of $C_{A}$,
Table 1. Fundamental properties of original bitumen

\begin{tabular}{|c|c|c|}
\hline Properties & Standard & Results \\
\hline Penetration (0.1 mm). 100 g. $5 \mathrm{~s}$ & ASTM D5 & 57 \\
\hline Softening point $\left[{ }^{\circ} \mathrm{C}\right]$ & ASTM D36 & 48 \\
\hline Viscosity (cP. $\left.135^{\circ} \mathrm{C}\right)$ & ASTM D4402 & 675 \\
\hline Viscosity (cP. $\left.165^{\circ} \mathrm{C}\right)$ & ASTM D4402 & 175 \\
\hline $\mathrm{G}^{*} / \sin \delta\left(\mathrm{kPa} .58^{\circ} \mathrm{C}\right)$ & AASHTO T5 & 4.37 \\
\hline Penetration Index (PI)* & - & -1.41 \\
\hline \multicolumn{3}{|l|}{ After TFOT } \\
\hline Mass loss [\%] & ASTM D2872 & 0.93 \\
\hline Penetration (0.1 mm). 100 g. $5 \mathrm{~s}$ & ASTM D5 & 33 \\
\hline Retained penetration [\%] & - & 58 \\
\hline Softening point $\left[{ }^{\circ} \mathrm{C}\right]$ & ASTM D36 & 56 \\
\hline Increase in softening point $\left[{ }^{\circ} \mathrm{C}\right]$ & - & 8 \\
\hline Penetration Index & - & -0.72 \\
\hline \multicolumn{3}{|c|}{$\begin{array}{l}\text { * PI calculated with the following equation: } \\
P I=\frac{1952-500 \cdot \log \left(P e n_{25}\right)-20 \cdot S P}{50 \cdot \log \left(P e n_{25}\right)-S P-120}\end{array}$} \\
\hline
\end{tabular}

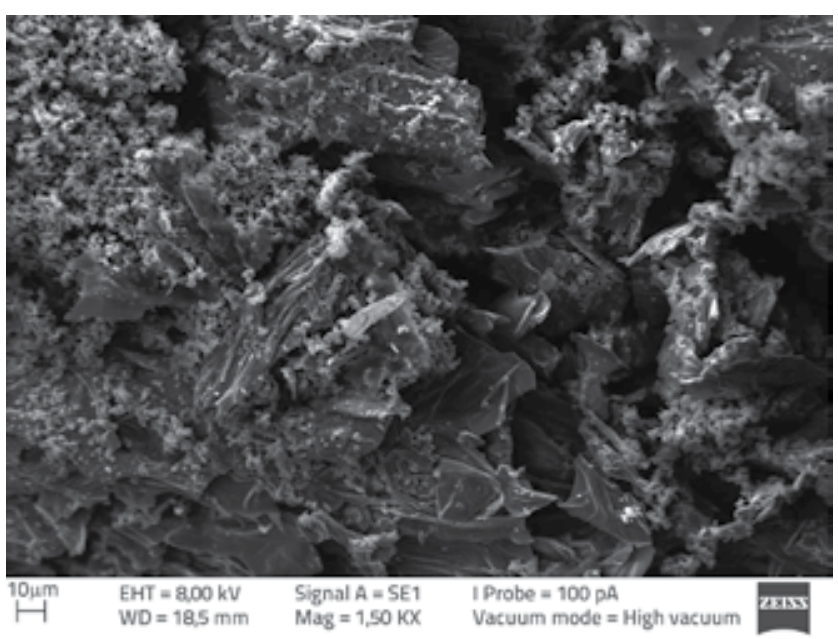

Figure 1. Surface texture of $C_{A}$

Table 2. Specifications of $C_{A}$

\begin{tabular}{|l|c|}
\hline Specification & $\mathbf{C}_{\mathbf{A}}$ \\
\hline Fixed carbon [\%] & 49.2 \\
\hline Volatile matter [\%] & 44.6 \\
\hline Ash [\%] & 6.0 \\
\hline Moisture content [\%] & 4.9 \\
\hline Density [g/cm $\left.{ }^{3}\right]$ & 1.96 \\
\hline Appearance & Black \\
\hline Shape of grains & Amorphous \\
\hline
\end{tabular}


with macropores, micropores, and mesopores that disperse to the surface heterogeneously, is shown in a scanning electron microscope photograph (Figure 1). The specifications of $C_{A}$ are summarized in Table 2.

\subsection{Preparation of modified bitumens}

Modified bitumens were prepared at a mixing temperature of $150^{\circ} \mathrm{C}$ by means of a laboratory Marshall mixer rotating at 500 rpm. $C_{A}$ was added to hot bitumen at ratios varying between 1 and $25 \%(w / w)$ and mixed for 45 minutes. $C_{A}$ size categories were chosen as size $1(<0.063 \mathrm{~mm})$, size $2(0.063-0.125 \mathrm{~mm})$, and size 3 (0.125-0.25 mm) (Figure 2). To avoid agglomeration of $C_{A}$ in the bitumen, and to ensure the homogeneity of mixtures, $C_{A}$ was added in small amounts $[4,6]$.

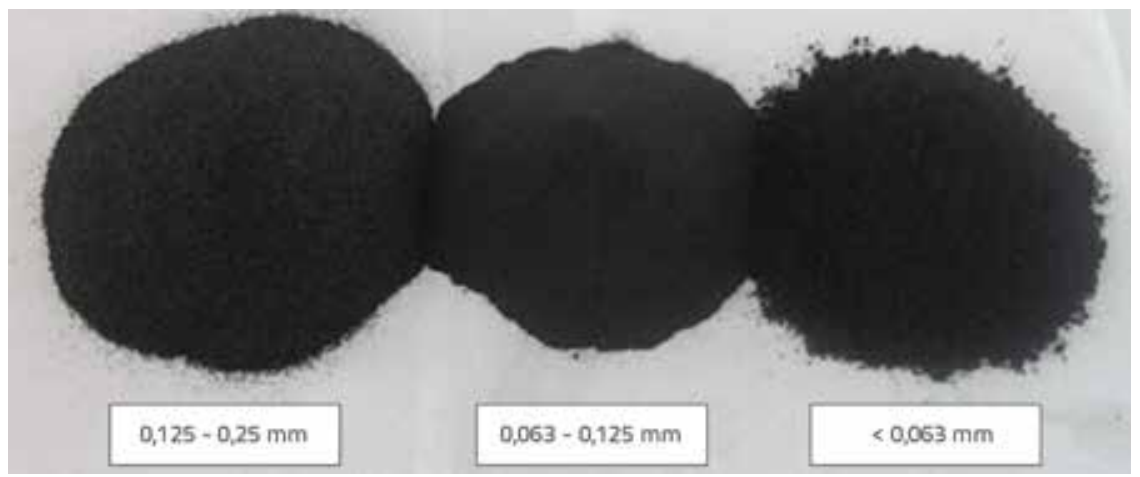

Figure 2. $C_{A}$ sizes

\section{Results and discussions}

\subsection{Softening point and penetration test results}

Original and modified bitumens were subjected to a standard ring and ball softening point test $[14,15]$ in order to determine consistency parameters. The softening point of the original bitumen amounted to $48^{\circ} \mathrm{C}$. As shown in Figure 3, softening point values of modified bitumens are higher than those of the original bitumen.

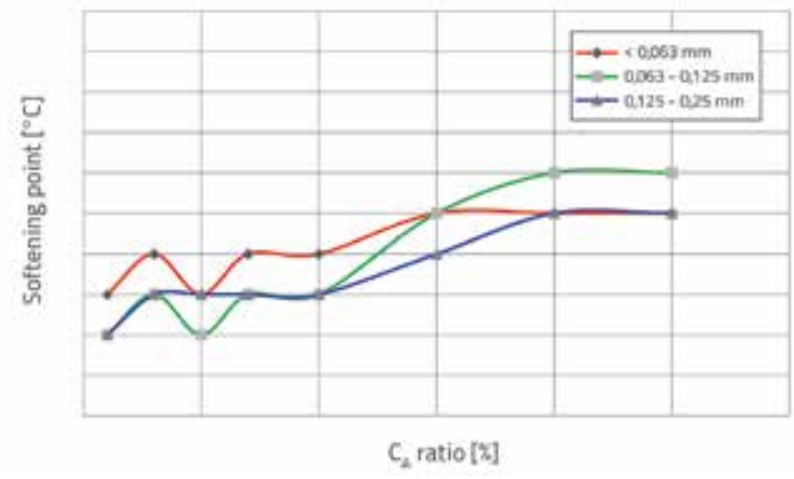

Figure 3. Softening point test results for modified bitumens
Table 3. Effective $C_{A}$ sizes and ratios

\begin{tabular}{|c|c|c|}
\hline Mixture number & $\mathbf{C}_{A}$ size $[\mathrm{mm}]$ & $\mathbf{C}_{A}$ ratio $[\%]$ \\
\hline 1 & $<0.063$ & 10 \\
\hline 2 & $<0.063$ & 15 \\
\hline 3 & $<0.063$ & 20 \\
\hline 4 & $0.63-0.125$ & 10 \\
\hline 5 & $0.63-0.125$ & 15 \\
\hline 6 & $0.63-0.125$ & 20 \\
\hline 7 & $0.125-0.25$ & 15 \\
\hline 8 & $0.125-0.25$ & 20 \\
\hline
\end{tabular}

The increase in softening point, especially at 10,15, and $20 \%$ ratios, is an indicator of the stiffening effect of $C_{A}$. The most effective $C_{A}$ sizes and ratios were determined based on the softening point test results for use in the latter tests. These values are given in Table 3.

The standard 100 gram, $25^{\circ} \mathrm{C}, 5$ second penetration test was carried out on the bitumens given in Table 3 . In addition, the temperature susceptibility of the bitumens was calculated in terms of penetration index (PI) using the results obtained during the penetration and softening point tests. Temperature susceptibility is defined as the change of consistency parameter as a function of temperature [14].

The effect of $C_{A}$ modification on the properties of original bitumen can be seen in Figure 4 , a decrease in penetration values and an increase in softening points occurs with an increase in $C_{A}$ content.

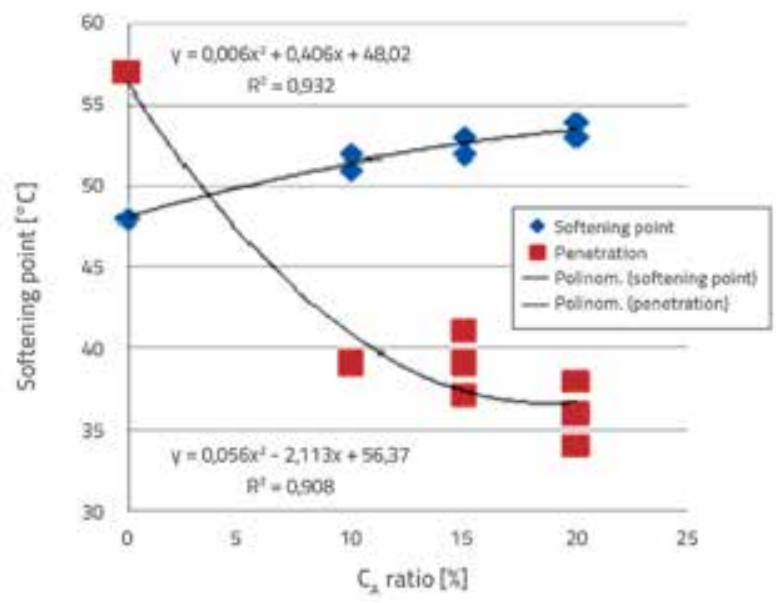

Figure 4. Correlations between softening point and penetration values and $C_{A}$ content

Correlations between the softening point and penetration values and the $C_{A}$ content are given in Figure 4 . High values of correlation coefficients $\left(0.93\right.$ and 0.91 ) confirm the $C_{A}$ dependence on 
penetration and softening point values. The increase in softening point is favourable since bitumen with a higher softening point is more resistant to rutting. $C_{A}$ modification reduced the temperature susceptibility (as determined by $\mathrm{Pl}$ ) of the original bitumen, especially at the $20 \%$ ratio. Lower values of PI indicate higher temperature susceptibility [14]. Size 1 was determined as the most effective size for $\mathrm{Pl}$ increase. The $20 \% \mathrm{C}_{\mathrm{A}}$ ratio with size 1 increased the PI value from -1.41371 to -0.96942 .

Table 4. Penetration, softening point, and PI results

\begin{tabular}{|c|c|c|c|}
\hline $\begin{array}{c}\text { Mixture } \\
\text { number }\end{array}$ & $\begin{array}{c}\text { Softening } \\
\text { point (SP) } \\
{\left[{ }^{\circ} \mathrm{C}\right]}\end{array}$ & $\begin{array}{c}\text { Penetration } \\
\mathbf{( 0 . 1} \mathbf{~ m m})\end{array}$ & $\begin{array}{c}\text { Penetration } \\
\text { Index (PI) }\end{array}$ \\
\hline $\begin{array}{c}\text { Original } \\
\text { bitumen }\end{array}$ & 48 & 57 & -1.41371 \\
\hline 1 & 52 & 39 & -1.25281 \\
\hline 2 & 53 & 39 & -1.02576 \\
\hline 3 & 54 & 36 & -0.96942 \\
\hline 4 & 51 & 39 & -1.48483 \\
\hline 5 & 53 & 37 & -1.13404 \\
\hline 6 & 54 & 34 & -1.08428 \\
\hline 7 & 52 & 41 & -1.14902 \\
\hline 8 & 53 & 38 & -1.07951 \\
\hline
\end{tabular}

\subsection{TFOT results}

The aging of bitumens was performed using the TFOT (thin film oven test) method (ASTM D 1754). Standardized conditions, that is, $163^{\circ} \mathrm{C}$ and 5 hours, were used [16]. The aged bitumens were evaluated by penetration and softening point tests. TFOT test results are presented in Figure 5 and Table $5 . C_{A}$ modification to the original bitumen reduced the weight loss percentage. As can be seen in Figure 5, the aging characteristics of original bitumen improve with an increase in the $C_{A}$ content.

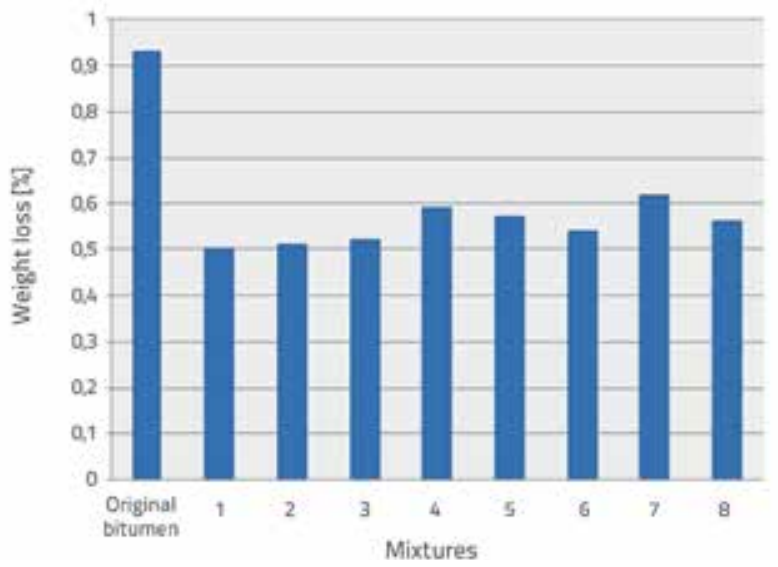

Figure 5. Weight loss percentages

This improvement can be explained by interactions between the functional groups of $C_{A}$ and volatile components of bitumen. As is evident from Figure 5, size 1 is the most effective size in terms of characteristics. The penetration and softening point tests conducted according to the TFOT method show that penetration values decrease, while softening point and PI values increase, in comparison with original bitumen.

Table 5. Bitumen characteristics after TFOT

\begin{tabular}{|c|c|c|c|}
\hline $\begin{array}{c}\text { Mixture } \\
\text { number }\end{array}$ & $\begin{array}{c}\text { Penetration } \\
\text { after TFOT } \\
\mathbf{( 0 . 1} \mathbf{~ m m )}\end{array}$ & $\begin{array}{c}\text { Softening point } \\
\text { after TFOT }\left[{ }^{\circ} \mathrm{C}\right]\end{array}$ & PI after TFOT \\
\hline $\begin{array}{c}\text { Original } \\
\text { bitumen }\end{array}$ & 33 & 56 & -0.72123 \\
\hline 1 & 30 & 59 & -0.31324 \\
\hline 2 & 27 & 59 & -0.51924 \\
\hline 3 & 29 & 59 & -0.38049 \\
\hline 4 & 28 & 58 & -0.64242 \\
\hline 5 & 25 & 59 & -0.66425 \\
\hline 6 & 24 & 60 & -0.55279 \\
\hline 7 & 27 & 60 & -0.33027 \\
\hline 8 & & 60 & -0.33027 \\
\hline
\end{tabular}

\subsection{DSR test results}

The DSR test was performed on original and $C_{A}$-modified bitumens using a Bohlin DSRII rheometer under the $120 \mathrm{~Pa}$ controlled stress at temperatures varying between $58-76^{\circ} \mathrm{C}$ with an increment of $6^{\circ} \mathrm{C}$ and the $10 \mathrm{rad} / \mathrm{s}$ frequency, using a 25 millimetre diameter plate with a $1 \mathrm{~mm}$ gap opening. In order to determine the high temperature properties of bitumen, complex shear modulus $\left(G^{*}\right)$, and phase angle $(\delta)$, the principal viscoelastic parameters were determined during the testing. $\mathrm{G}^{*} / \sin \delta$, which indicates the bitumen resistance to rutting under elevated temperatures, was calculated and compared with the Superpave asphalt bitumen test specifications as defined in AASHTO TP5. The specification shows that the $\mathrm{G}^{*} /$ $\sin \delta$ parameter is less than $1000 \mathrm{~Pa}$ for unaged bitumens [17, 18]. DSR test results ( $\mathrm{G}^{*} / \sin \delta$ values) are given in Figure 6-7.

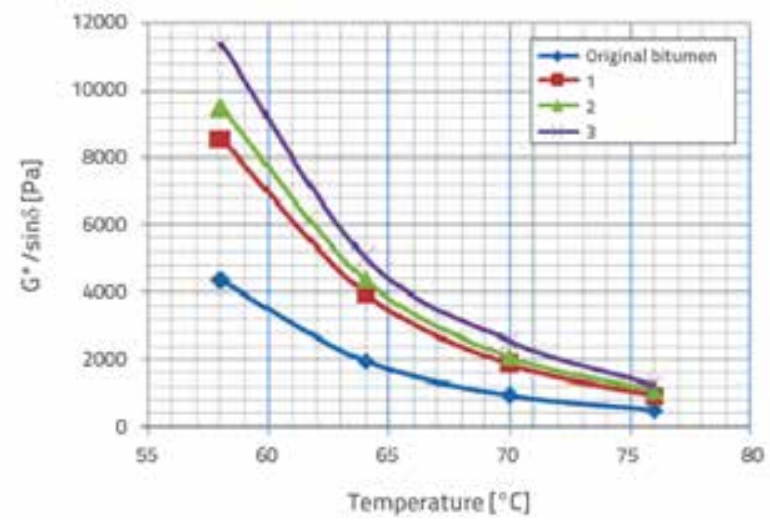

Figure 6. $\mathrm{G}^{*} / \sin \delta$ for original bitumen and mixtures 1, 2, and 3 (Size 1) 
Based on the Superpave PG grading system, the original bitumen exhibits $1000 \mathrm{~Pa}$ of $\mathrm{G}^{*} / \sin \delta$ at $64^{\circ} \mathrm{C}$. The high temperature performance of mixtures 1,4 , and 7 is $70^{\circ} \mathrm{C}$, while it amounts to $76^{\circ}$ for all other mixtures. As can be seen in Figures 6 and 7 , the rutting parameter improves with an increase in the $C_{A}$ content. Correlations between the $C_{A}$ content and improvement of $\mathrm{G}^{*} / \sin \delta$ values are given in Figure 8 . The $\mathrm{G}^{*} / \sin \delta$ values at $76^{\circ} \mathrm{C}$ with the $20 \%$ additive ratio show that sizes 1 and 2 have similar effects on the rutting parameter, while the worst value is obtained with size 3 . This can be explained by the separation of coarse $C_{A}$ and the resulting deterioration of homogeneity.

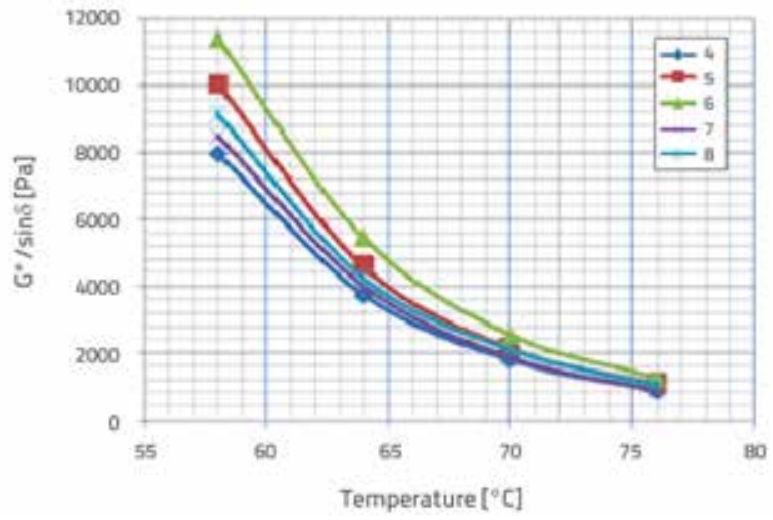

Figure 7. G*/sin $\delta$ for mixtures 4, 5, 6, 7, and 8 (Sizes 2 and 3)

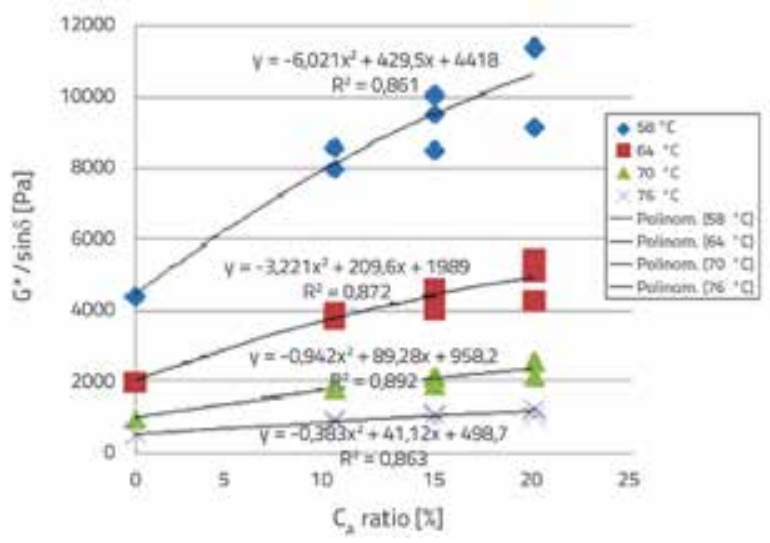

Figure 8. Correlations between $\mathrm{G}^{*} / \sin \delta$ and $\mathrm{C}_{\mathrm{A}}$ ratio

\subsection{RV test results}

The viscosity obtained by RV test is the measure of internal friction in bitumen. The viscosity at $135^{\circ} \mathrm{C}$ is usually used to measure workability according to Superpave specifications. The RV also measures rheological properties of bitumens to evaluate their ability to be pumped during delivery and plant operations. Therefore, elevated temperatures of $135^{\circ}$ and $165^{\circ} \mathrm{C}$ were used in this study for testing purposes $[17,19]$. The viscosity was determined by measuring the torque required to maintain constant rotation speed ( $20 \mathrm{rpm}$ ) of a cylindrical spindle submerged in bitumen maintained at a constant temperature [20]. RV test results at 135 and $165^{\circ} \mathrm{C}$ are given in Figure 9 .

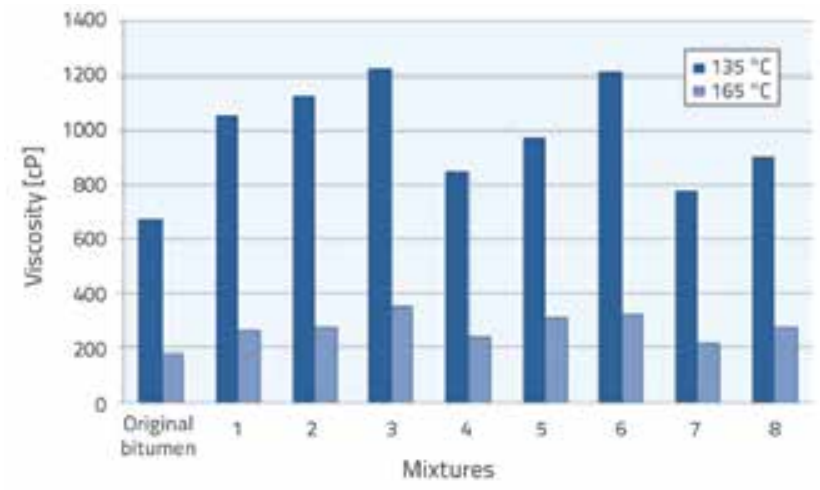

Figure 9. RV results of bitumens

The viscosities give a clear indication of the stiffening effect of $C_{A}$ modification with a high additive content. Size 1 is the most effective size in terms of viscosity increase for all ratios. It was determined that the viscosity for size $3 C_{A}$ mixtures with a 20 $\%$ additive ratio at $135^{\circ} \mathrm{C}$ is by $26 \%$ smaller compared to the remaining two sizes. The observed decrease in viscosity can be explained by the non-homogenous mixture evidenced in DSR results.

\section{Conclusions}

The following conclusions were drawn based on the test results:

- Bitumen stiffness and consistency clearly increase with an addition of $C_{A}$.

- According to softening point test results, the optimum additive ratio varies between 10 and $20 \%$.

- PI values show that the temperature susceptibility of original bitumen decreases with $C_{A}$ modification. In particular, size 1 and the $20 \%$ additive ratio are the most effective conditions for preventing temperature susceptibility.

- $C_{A}$ modification affects the ageing characteristics of original bitumen and decreases the weight loss percentage.

- In the DSR test, $C_{A}$ modification yields higher $G^{*} / \sin \delta$ values. When comparing the three different sizes, size 3 performs worse than the other two sizes. The reduction of rutting parameter in case of size 3 is a result of separation of coarse $C_{A}$ and deterioration of homogeneity.

- Viscosity increases and workability decreases when bitumen is modified with $C_{A}$.

\section{REFERENCES}

[1] Yu, J., Zeng, X., Wu, S., Wang, L., Liu, G.: Preparation and properties of montmorillonite modified asphalts, Mater SciEng, 447 (2007), pp. 233-238, https://doi.org/10.1016/j.msea.2006.10.037
[2] Martinez, A., Paez, A., Martin, N.: Rheological modification of bitumens with new poly-functionalized furfural analogs, Fuel, 87 (2008), pp. 1148-1154, https://doi.org/10.1016/j. fuel.2007.07.010 
[3] Kok, B.V., Yilmaz, M., Sengoz, B., Sengur, A., Avci, E.: Investigation of complex modulus of base and SBS modified bitumen with artificial neural networks, Expert SystAppl, 37 (2010), pp. 77757780, https://doi.org/10.1016/j.eswa.2010.04.063

[4] Zhang, J., Wang, J., Wu, Y., Wang, Y., Wang, Y.: Evaluation of the improved properties of SBR/weathered coal modified bitumen containing carbon black, Constr Build Mater, 23 (2009), pp. 26782687, https://doi.org/10.1016/j.conbuildmat.2008.12.020

[5] Arslan, D., Gürü, M., Çubuk, M.K., Çubuk, M.: Improvement of bitumen and bituminous mixtures performances by triethylene glycol based synthetic polyboron, Constr Build Mater, 25 (2011), pp. 3863-3868, https://doi.org/10.1016/j.conbuildmat.2011.04.007

[6] Chebil, S., Chaala, A., Roy, C.: Use of softwood bark charcoal as a modifier for road bitumen, Fuel, 79 (2000), pp. 671-683, https:// doi.org/10.1016/S0016-2361(99)00196-9

[7] Șen, N.: Production of activated carbon from hazelnut shell and its characterization, Elazığ Turkey, Fırat University, MSc thesis, 2009.

[8] Çuhadar, C..: Production and characterization of activated carbon from hazelnut shell and hazelnut husk, Ankara Turkey, Middle East Technical University, MSc thesis, 2005.

[9] Hayashi, J., Kazehaya, A., Muroyama, K., Watkinson, A.P.: Preparation of activated carbon from lignin by chemical activation, Carbon, 38 (2000) pp. 1873-1878, https://doi.org/10.1016/ S0008-6223(00)00027-0

[10] Guo, J., Xu, W.S., Chen, Y.L., Lua, A.C.: Adsorption of $\mathrm{NH}_{3}$ onto activated carbon prepared from palm shells impregnated with $\mathrm{H}_{2} \mathrm{SO}_{4^{\prime}}$ J Colloid InterfSci, 281 (2005), pp. 285-290, https://doi. org/10.1016/j.jcis.2004.08.101

[11] Sabio, M.M., Reinoso, F.R.: Role of chemical activation in the development of carbon porosity, Colloid Surface A, 241 (2004), pp. 15-25, https://doi.org/10.1016/j.colsurfa.2004.04.007
[12] Akyld Iz, H.: Production of activated carbon from olive stones with $\mathrm{H}_{3} \mathrm{PO}_{4}$ activation, Istanbul Turkey, Istanbul Technical University, MSc thesis, 2007.

[13] Kim, D.S.: Activated carbon from peach stones using phosphoric acid activation at medium temperatures, J Environ Sci Heal A, 39 (2004) 5, pp. 1301-1318, https://doi.org/10.1081/ESE120030333

[14] Sengoz, B., Isikyakar, G.: Evaluation of the properties and microstructure of SBS and EVA polymer modified bitumen, Constr Build Mater, 22 (2008), pp. 1897-1905, https://doi.org/10.1016/j. conbuildmat.2007.07.013

[15] Hadavand, B.S.: Bitumen modification with polysulphide polymer prepared from heavy end waste, Iran Polym J, 19 (2010) 5, pp. 363-373.

[16] Lu, X., Isacsson, U.: Effect of ageing on bitumen chemistry and rheology, Constr Build Mater, 16 (2002), pp. 15-22, https://doi. org/10.1016/S0950-0618(01)00033-2

[17] Kök, B.V., Çolak, H.: Laboratory comparison of the crumb-rubber and SBS modified bitumen and hot mix asphalt, Constr Build Mater, 25 (2011), pp. 3204-3212, https://doi.org/10.1016/j. conbuildmat.2011.03.005

[18] Kök, B.V., Yilmaz, M., Guler, M.: Evaluation of high temperature performance of SBS + gilsonite modified binder, Fuel, 90 (2011), pp. 3093-3099, https://doi.org/10.1016/j.fuel.2011.05.021

[19] Zargar, M., Ahmadinia, E., Asli, H., Karim, M.R.: Investigation of the possibility of using waste cooking oil as a rejuvenating agent for aged bitumen, J Hazard Mater, 233-4 (2012), pp. 254-258, https:// doi.org/10.1016/j.jhazmat.2012.06.021

[20] Yilmaz, M., Kok, B.V.: Effects of ferrochromium slag with neat and polymer modified binders in hot bituminous mix, Indian J Eng Mater S, 16 (2009), pp. 310-318. 